\title{
THE PREDOMINANT CULTIVABLE FLORA OF TOOTH SURFACE PLAQUE REMOVED FROM INSTITUTIONALIZED SUBJECTS
}

\author{
W. J. Loesche, R. N. HocketT and S. A. Syed \\ Department of Oral Biology, University of Michigan, School of Dentistry, \\ Ann Arbor, Michigan 48104, U.S.A.
}

\begin{abstract}
Summary-Tooth surface plaque was removed from 11 institutionalized individuals and cultured on agar plates in an anaerobic chamber. The recovery of organisms on a dilute trypticase yeast extract medium (MM10), incubated anaerobically, averaged $33 \pm 26$ per cent of the microscopic count. Growth on MM10, under aerobic conditions averaged $8 \pm 5$ per cent. The anaerobe to aerobe recovery ratio on medium MM10 was about 4. Six hundred and seventy-one isolates grew on subculture and were partially characterized. About half the isolates were not capable of lowering the $\mathrm{pH}$ in glucose broth below $5 \cdot 5$. Streptococci accounted for about 38 per cent of the isolates and were found in each subject. A sub-group of 15 strains grew in 40 per cent bile, formed $\mathrm{NH}_{3}$ from arginine, fermented salicin, but not inulin. These isolates possessed characteristics of Streptococcus sanguis and Streptococcus mitis. Various Actinomyces species comprised about 14 per cent and Clostridium species accounted for 8 per cent of the cultivable flora. Bacteroides melaninogenicus, Fusobacterium species, and Veillonella species each were about 6 per cent of the isolates. The overall character of these plaque isolates suggested that a gingival crevice microflora containing several amino-acid fermenting species had colonized the tooth surfaces. These organisms would not be expected to produce a plaque capable of decalcifying enamel, which might explain why these subjects had a low caries experience.
\end{abstract}

\section{INTRODUCTION}

ThE DENTOGINGIVAL surfaces are colonized by a dense microbial population, i.e. $>10^{11}$ bacteria per gram wet weight (SOCRANSKY $e t$ al., 1963; THEILADE and THEILADE, 1969; GoRdon, StutMAN and LoESCHE, 1971). This microbial flora is part of a complex ecosystem referred to clinically as dental plaque. Certain plaques, which form on the tooth and gingival surfaces, contribute to the disease processes which occur on or in these structures. As these pathologies have components which are dissimilar, i.e. decalcification leading to caries, and calcification leading to calculus formation, the bacteria isolated from these plaques should reflect these differences. Quantitative cultural studies have shown that tooth surface plaque obtained from individuals with low to moderate caries experience contains a high percentage of acidogenic organisms with Streptococci species and Gram-positive rods predominating (GibBons et al., 1964). The preponderance of acidogenic organisms in tooth surface plaque is compatible with the decalcification that can occur on these surfaces. Gingival crevice plaque contains, in addition to the various acidogenic organisms, several species such as 
Bacteriodes melaninogenicus, Fusobacterium nucleatum, Treponema dentium, and Peptococcus species (GibBons et al., 1963) which derive energy from amino acid catabolism with the formation of ammonia and various fatty acids (LOESCHE, 1968). Ammonia as a strong base would be available to neutralize the acids formed from fermentation and to act as a tissue irritant (MacDonald and GibBons, 1962; Rizzo, 1967). The presence of these amino-acid fermenting species might explain why gingival plaque $\mathrm{pH}$ is close to neutrality (KLEINBERG, 1970) and consequently why calculus formation and not caries is a likely event in the gingival crevicular area.

The present investigation of tooth surface plaque in institutionalized subjects was undertaken in order to determine whether their plaque flora would reflect the clinic differences between them and the population sampled by GiBBons et al. (1964).

\section{MATERIALS AND METHODS}

\section{Subjects}

Eleven institutionalized subjects, aged 11-22 yr and residents of a single dormitory at the Plymouth State Home and Training School, Northville, Michigan, were studied. At the time of sampling, these subjects had a gingivitis score of $2.54 \pm 0.44$ (RAMFJoRD, 1959). About $19 \pm 23 \mathrm{mg}$ plaque dry weight could be removed from the buccal surfaces of the 6 teeth used in the Ramfjord scoring system. The higher plaque weights were due to heavy calculus deposits in some individuals. No mongoloids were included. The subjects had various neurological and mental disorders and some were under medication for these problems.

\section{Sample collection}

The oral flora appears to be sensitive to short exposures to atmospheric oxygen (GoRDON, STUTMAN and LOESCHE, 1971). Because our samples were collected in the field and were some 2-3 hr away from the anacrobic chamber, precautions were taken to minimize oxygen exposure of the samples. The teeth to be sampled were not air dried. Buccal surface plaque was removed with periodontal scalers from the maxillary left second premolar, maxillary left first molar, mandibular right second premolar, and mandibular right first molar. The plaque was immediately placed in $1 \mathrm{ml}$ of a reduced transport fluid (RTF), Table 1, contained in a shell vial. The shell vials containing the samples were cork stoppered and had minimal, if any, air space. The vials were placed into a jar made anaerobic with a Gas Pak (Bioquest) and returned to the laboratory. The RTF contained no nutritives and because of the dithiothreitol (DTT) would be expected to have a low Eh (CLELAND, 1964). Plaque from other teeth in the subject was removed at the same time, weighed, and its microscopic bacterial count determined. As the microscopic counts of the cultured plaque were also determined, it was possible by a simple proportional equation to calculate the weight and bacterial density of the cultured plaque.

\section{Sample dispersion and plating}

The vial containing the plaque was introduced into a plastic anaerobic chamber (ARANKI et al., 1969) containing an atmosphere of 85 per cent $\mathrm{N}_{2}, 10$ per cent $\mathrm{H}_{2}$ and 5 per cent $\mathrm{CO}_{2}$. All subsequent manipulations and incubations were performed in the chamber. The aluminium foil around the vial and the cork stopper were removed from the vial. The vial was dropped intact into $100 \mathrm{ml}$ of RTF contained in a Waring Blender. The vial and its contents were then disrupted by mixing in the blender for $2 \mathrm{~min}$. Aliquots from the blender dilution were: (1) stained with buffered formalin gentian violet dye and a microscopic count was obtained using the Petroff Hauser counting chamber (ARANKI et al., 1969; SPEARs and FreTer, 1967); (2) saved for subsequent fluorescent antibody examination; and (3) carried through a serial 10-fold dilution in RTF. The buffered formalin gentian violet dye had been passed through a $0.45 \mu \mathrm{m}$ membrane filter to remove particles which could be confused with bacteria. The aliquot from the blender dilution was mixed by a Vortex mixer prior to counting. Each suspension was stained with the gentian violet and allowed to settle for $30 \mathrm{~min}$ in the counting chamber. Duplicate counts were made routinely; and when the results differed by more than 10 per cent, repeat determinations were performed. All counts were performed as soon as possible after collection by the same individual. 


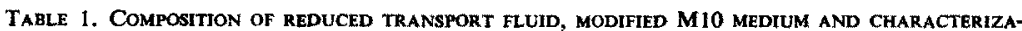
TION BROTH

\begin{tabular}{|c|c|}
\hline Reduced transport fluid (RTF) & Additions per $100 \mathrm{ml}$ \\
\hline $\begin{array}{l}0.04 \% \mathrm{Na}_{2} \mathrm{CO}_{3}{ }^{*} \\
0.001 \mathrm{M} \mathrm{EDTA}^{2} \mathrm{MDT}^{*} \\
0.02 \% \mathrm{Dithiothreitol}^{*} \\
0.045 \% \mathrm{~K}_{2} \mathrm{H} \mathrm{PO} \mathrm{PO}_{4} \\
0.045 \% \mathrm{~K} \mathrm{H}_{2} \mathrm{PO}_{4} \\
0.09 \% \mathrm{NaCl} \mathrm{SaCO}_{4} \\
0.09 \%\left(\mathrm{NH}_{4}\right)_{2} \mathrm{SO}_{4} \\
0.018 \% \mathrm{MgSO}_{4}\end{array}$ & $\begin{array}{l}0.5 \mathrm{ml} \text { of stock solution } 8 \% \mathrm{Na}_{2} \mathrm{CO}_{3} \\
1.0 \mathrm{ml} \text { of } 0.1 \mathrm{M} \text { EDTA stock solution } \\
2.0 \mathrm{ml} \text { of } 1 \% \mathrm{DTT} \text { stock solution } \\
7.5 \mathrm{ml} \text { of } 0.6 \% \mathrm{~K}_{2} \mathrm{HPO} \text { stock solution } \\
7.5 \mathrm{ml} \text { of stock mineral solution containing } \\
\left.\begin{array}{l}0.6 \% \mathrm{KH}_{2} \mathrm{PO}_{4} \\
1.2 \% \mathrm{NaCl} \\
1.2 \%\left(\mathrm{NH}_{4}\right)_{2} \mathrm{SO}_{4} \\
0.25 \% \mathrm{Mg} \mathrm{SO}_{4}\end{array}\right\} \text { SMS }\end{array}$ \\
\hline
\end{tabular}

Modified M10 Medum

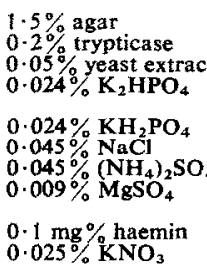

$\mathrm{KNO}_{3}$

Autoclave above, then add aseptically

$3 \%$ sheep blood

$0.1 \%$ glucose

$0+04 \% \mathrm{Na}_{2} \mathrm{CO}_{3} *$

$0.012 \%$ cysteine

$0.01 \%$ dithiothreitol

Menadione* $0.5 \mu \mathrm{g} / \mathrm{ml}$

Falty acids
$3 \cdot 8 \mathrm{ml}$ of $0.6 \%$ stock solution

$3.8 \mathrm{ml}$ of stock mineral solution

$1 \mathrm{ml}$ of $10 \mathrm{mg} \%$ stock solution

$0.5 \mathrm{ml}$ of $5 \%$ stock

$1 \mathrm{ml}$ of stock $10 \%$ glucose

$0.5 \mathrm{ml}$ of $8 \% \mathrm{Na}_{2} \mathrm{CO}_{3}$

$0.5 \mathrm{ml}$ of stock $2.5 \%$ solution

1 mil of stock $1 \%$ DTT

$0.1 \mathrm{~m}$ of stock containing $50 \mathrm{mg} / 100 \mathrm{~m}$ ?

$0.5 \mathrm{ml}$ of stock solution containing

Acetic

Propionic

N-butyric

Iso-butyric

$\mathrm{N}$-valeric

Iso-valeric

DI -2-methyl-n-butyric

Lactic $(88 \%)$

Formic $(88 \%) \quad 2 \mathrm{ml}$

Make up to $100 \mathrm{ml}$ with sterile

distilled $\mathrm{H}_{2} \mathrm{O}$

\section{Characterization Broth}

$1 \%$ tryptone

$0.5 \%$ yeast extract

$1 \%$ veal infusion broth

$5 \%$ gelatin

$0.025 \% \mathrm{KNO}_{3}$

$0.1 \mathrm{mg} \%$ Haemin

$0.5 \mathrm{mi}$ of $5 \%$ stock

$1 \mathrm{mi}$ of $10 \mathrm{mg} \%$ stock

$0.024 \% \mathrm{KH}_{2} \mathrm{PO}_{4}$

$0.045 \% \mathrm{NaCl}$

$0.045 \%\left(\mathrm{NH}_{4}\right)_{2} \mathrm{SO}_{4}$

$0.009 \% \mathrm{MgSO}_{4}$

$3 \cdot 8 \mathrm{ml}$ of stock mineral solution

Autoclave above, then add aseptically

$0.5 \%$ glucose

$0.12 \%$ cysteine

Menadione $0.5 \mu \mathrm{g} / \mathrm{ml}$

$0.1 \mathrm{ml} 50 \mathrm{mg} \%$ stock

* Filter sterilized $0.22 \mu \mathrm{m}$ filter.

t Enough sterile 40 per cent $\mathrm{NaOH}$ is added to $\mathrm{pH}$ the medium to $6 \cdot 8-7 \cdot 2$.

After the plaque suspension had been serially diluted, suitable aliquots were placed on mitis salivarius tellurite agar medium (MST) (Difco) and on a supplemented dilute trypticase, yeast extract agar, Table 1. This medium, designated hereon as MM10, is a modification of the M10 rumen fuid formulation of CALDWELL and BRYANT (1966), and was an attempt to provide the known nutrient requirements of the oral flora (LOESCHE and GIBBONS, 1966) in the hope that these additives would permit the growth of more plaque species. Because of the complexity of the medium, it was prepared 
in large batches and frozen until used. Subsequent studies suggested that the volatile fatty acids could be omitted (unpublished data).

A membrane filter technique was used to harvest bacteria from the serial dilutions. One $\mathrm{ml}$ aliquots of the appropriate dilution were placed on the surfaces of $0.22 \mu \mathrm{m}$ filters supported in a plastic filtering apparatus (Sterifil Unit, Millipore Corp., Bedford, Mass.). The liquid was drawn through the filter and then the filter containing the impinged bacterial cells was placed on the surfaces of the agar media. This filter procedure gave slightly higher counts when compared with the glass rod spreading technique. As the filters could be removed and saved, this procedure provided a means of preserving the colonies that were present in the primary isolation. Conceivably, at some future time, upon development of suitable fluorescent antibody reagents, these colonies could be identified or confirmed (DANielsson, 1965; JAblon, FerRer and Zinner, 1971).

\section{Partial characterization of isolates}

The MST plates were incubated anaerobically for 1-2 days and then left overnight aerobically at room temperature. Colonial growth on this medium was examined under the dissecting microscope, and colonies resembling Streptococcus mutans, Strep. sanguis, and Strep. salivarius enumerated. The MM10 plates were incubated both anaerobically and aerobically. After 5-7 days incubation, the number of colonies on the plates were counted. One anaerobic MM10 plate from each child containing well isolated colonies was selected for further study. Each colony was subcultured on MM10 agar for a purity check. This was necessary because some of the primary colonies were mixtures of 2 or more bacterial types on Gram stain. Isolates pure by Gram stain and darkfield examination were subcultured to a characterization broth (CB), Table 1. After growth in this medium, the following tests were performed: terminal $\mathrm{pH}, \mathrm{H}_{2} \mathrm{~S}$ production determined by blackening of lead acetate strips, nitrate reduction, gelatin liquefaction, and indole production following methods described by the SOCIETY OF AMERICAN MICROBIOLOGISTs (1957). Growth from the CB was streaked on MM10 plates and incubated aerobically. Gram stain and darkfield examinations of growth in the CB were performed. Representative strains were subcultured in peptone yeast extract glucose broth (PYG). After growth occurred, the acid end-products were determined using the gas-liquid chromatographic procedures recommended by the Anaerobic Laboratory at Virginia Polytechnic Institute (ANAERoBe LAB., 1970).

\section{RESULTS}

A major difficulty in the quantitative recovery of bacteria from a dense microbial mat such as plaque is the dispersion and separation of the aggregation into single cells. The plaque obtained from these institutionalized subjects was difficult to disperse into single cells as judged by microscopic observation. Each cell or clump was counted as a single microscopic unit and the recoveries on the various media are reported as a percentage of the total number of microscopic units. A significant improvement in microscopic unit count was achieved by the addition of $0.001 \mathrm{M}$ EDTA to the RTF. The original formulation for the RTF had 0.0045 per cent $\mathrm{CaCl}_{2}$ and no EDTA. Plaque collected and dispersed in RTF with $\mathrm{CaCl}_{2}$ had a microscopic density of $6.6 \pm 4.5 \times 10^{8}$ cells $/ \mathrm{mg}$ dry weight. When the $\mathrm{CaCl}_{2}$ was deleted and $0.001 \mathrm{M}$ EDTA added to the RTF, the microbial density increased two-fold to $13 \cdot 0 \pm 4 \cdot 3$ $10^{8} / \mathrm{mg}$ dry wt. This difference was highly significant by the Student $t$-test, i.e. $p<0 \cdot 01$, where $n=74$. Even so, about $10-15$ per cent of the microscopic units in the EDTA treated plaque contained 2 or more cells.

The dispersed plaque dilutions were plated $2-3 \mathrm{hr}$ after their collection. The recovery of organisms on anaerobically incubated MM10 medium averaged $33 \cdot 3 \pm 25 \cdot 9$ per cent (Table 2) of the microscopic count. Growth on MM10 under aerobic conditions averaged $8 \cdot 3 \pm 5 \cdot 4$ per cent, whereas growth anaerobically on the MST medium averaged $7 \cdot 6 \pm 9 \cdot 0$ per cent. The anaerobic to aerobic recovery ratio on MM10 medium was about 4 (Table 2). 
TABle 2. Recovery of bacteria from supragingival plaque of institutionalized CHILDREN $(\mathrm{n}=11)$

\begin{tabular}{|c|c|c|c|}
\hline Media & Viable count & $\%$ Reco & very* \\
\hline $\begin{array}{l}\text { MMLO† } \\
\text { Anaerobic } \\
\text { Aerobic } \\
\text { MST }\end{array}$ & $\begin{array}{l}4 \cdot 3 \pm 3.3 \times 10^{8} \S / \mathrm{mg} \text { dry wt } \\
1 \cdot 1 \pm 0 \cdot 7 \\
1 \cdot 0 \pm 1 \cdot 2\end{array}$ & $\begin{array}{l}33 \cdot 3 \pm 25 \cdot 98 \\
8 \cdot 3 \pm 5 \cdot 4 \\
7 \cdot 6 \pm 9 \cdot 0\end{array}$ & $p=0.01$ \\
\hline
\end{tabular}

* Recovery $=$ viable count divided by microscopic count $\times 100$.

† Modified M10 medium: CaldWElL and BRYANT (1966).

\$ Mitis salivarius tellurite medium.

$\$$ Plus or minus standard deviation.

Six hundred and seventy-one isolates grew on subculture and were partially characterized. A considerable number of these isolates were not capable of lowering the $\mathrm{pH}$ in the characterization broth below $5 \cdot 5$ (Table 3 ). Thirty-three per cent of the isolates

Table 3. Predominant cultivable flora of institutionalized children

\begin{tabular}{lcccc}
\hline Subject & $\begin{array}{c}\text { Number of } \\
\text { isolates }\end{array}$ & \multicolumn{3}{c}{$\begin{array}{c}\text { Per cent distribution of isolates according } \\
\text { to terminal pH in glucose broth (CB)* }\end{array}$} \\
\hline J.L. & $65 \cdot 5 \mathrm{pH}$ & $5 \cdot 5-6 \cdot 5 \mathrm{pH}$ & $>6 \cdot 5 \mathrm{pH}$ \\
\hline E.G. & 67 & 67 & $1 \cdot 5$ & $31 \cdot 5$ \\
C.M. & 67 & 70 & $8 \cdot 5$ & $21 \cdot 5$ \\
L.H. & 64 & $65 \cdot 5$ & 19 & $31 \cdot 5$ \\
C.C. & 76 & 45 & 12 & 50 \\
D.B. & 46 & 38 & 26 & 38 \\
B.B. & 85 & 46 & 18 & 47 \\
J.B. & 76 & 48 & 93 & 22 \\
W.J. & 40 & $34 \cdot 5$ & 24 & 23 \\
B.G. & 37 & 54 & $28 \cdot 4$ & $32 \cdot 9 \pm 9 \cdot 4 \dagger$ \\
R.S. & 67 & 49 & $16 \cdot 6 \pm 10 \cdot 5 \dagger$ & \\
Total & 671 & $50 \cdot 8 \pm 12 \cdot 1 \dagger$ & & \\
\hline
\end{tabular}

* CB characterization broth.

$\dagger$ Plus or minus standard deviation.

appeared to be nonfermentative and 17 per cent were weakly fermentative as they lowered the $\mathrm{pH}$ between $5 \cdot 5-6 \cdot 5$. The isolates were grouped according to the limited number of tests performed. The major types of bacteria found could be placed in recognized genera and given species identification in some instances. The response of the isolates in the $\mathrm{NO}_{3}$ and $\mathrm{H}_{2} \mathrm{~S}$ tests facilitated the grouping of the unidentified organisms. A summary table showing the main groupings is given in Table 4.

\section{Gram-positive cocci}

The Gram-positive cocci were the largest morphologic group recognized and were found in each subject. The majority of these isolates were acidogenic, facultative, catalasc-ncgative, nitrate-negative, indolc-negative, gelatin-negativc, $\mathrm{H}_{2} \mathrm{~S}$-negative streptococci. Representative strains formed acetic and lactic acids in PYG broth. These isolates were not Strep. salivarius or Strep. mutans as determined by colony morphology on the MST plates. Fifteen strains were studied in greater detail and the results obtained are given in Table 5. The majority of these selected strains grew in 40 per cent bile, formed $\mathrm{NH}_{3}$ from arginine (Niven, SMiley and SHerman, 1942), reduced methylene-blue milk forming an acid clot and fermented salicin but not inulin or mannitol. They did not agglutinate with commercially obtained streptococcal group 
Table 4. Predominant cultivable organisms isolated from institutionalized childoren

\begin{tabular}{|c|c|c|c|c|}
\hline Species & $\underset{\substack{\text { Number of } \\
\text { isolates }}}{ }$ & $\begin{array}{l}\% \text { Viable } \\
\text { colnt }\end{array}$ & $\begin{array}{l}\text { Range in } \\
\% \text { viable }\end{array}$ & Occurrence* \\
\hline $\begin{array}{l}\text { Gram-positive cocci } \\
\text { Streptococci sp. } \\
\text { Unidentified }\end{array}$ & $\begin{array}{l}271 \\
247\end{array}$ & $\begin{array}{l}41 \cdot 5 \\
37 \cdot 8\end{array}$ & $16-66$ & $11 / 11$ \\
\hline $\begin{array}{l}\mathrm{NO}_{3}-\mathbf{H}_{2} \mathbf{S}- \\
\mathrm{NO}_{3}-\mathbf{H}_{2} \mathbf{S}\end{array}$ & $\begin{array}{r}15 \\
9\end{array}$ & $\frac{2 \cdot 3}{1 \cdot 4}$ & $\begin{array}{l}0-10 \\
0-7\end{array}$ & $\begin{array}{l}6 / 11 \\
2 / 11\end{array}$ \\
\hline $\begin{array}{l}\text { Gram-positive rods } \\
\text { Clostridium sp. } \\
\text { Actinomyces sp. } \\
\text { Unidentified }\end{array}$ & $\begin{array}{r}232 \\
55 \\
93\end{array}$ & $\begin{array}{r}35 \cdot 3 \\
8 \cdot 4 \\
14 \cdot 2\end{array}$ & $\begin{array}{l}0-39 \\
4-33\end{array}$ & $\begin{array}{l}11 / 11 \\
8 / 11 \\
11 / 11\end{array}$ \\
\hline $\begin{array}{l}\mathbf{N O}_{3}+\mathbf{H}_{2} \mathbf{S}^{+} \\
\mathbf{N O}_{3}-\mathbf{H}_{2} \mathbf{S}^{-} \\
\mathbf{N O}_{3}-\mathbf{H}_{2} \mathbf{S}^{+}\end{array}$ & $\begin{array}{l}12 \\
25 \\
47\end{array}$ & $\begin{array}{l}1 \cdot 8 \\
3 \cdot 8 \\
7 \cdot 1\end{array}$ & $\begin{array}{l}0-14 \\
0-21 \\
0-22\end{array}$ & $\begin{array}{r}5 / 11 \\
7 / 11 \\
10 / 11\end{array}$ \\
\hline $\begin{array}{l}\text { Gram-negative rods } \\
B, \text { melaninogenicus } \\
\text { Fusobacterium sp. } \\
\text { Unidentified }\end{array}$ & $\begin{array}{r}111 \\
37 \\
45\end{array}$ & $\begin{array}{r}16 \cdot 9 \\
5.6 \\
6.8\end{array}$ & $\begin{array}{l}0-22 \\
0-18\end{array}$ & $\begin{array}{r}11 / 11 \\
8 / 11 \\
9 / 11\end{array}$ \\
\hline $\begin{array}{l}\mathrm{NO}_{3}-\mathrm{H}_{2} \mathrm{~S}^{-} \\
\mathrm{NO}_{3}+\mathrm{H}_{2} \mathbf{S}^{-}\end{array}$ & $\stackrel{14}{15}$ & $\begin{array}{c}2 \cdot 1 \\
2 \cdot 3\end{array}$ & $\begin{array}{c}0-20 \\
0-11\end{array}$ & $\begin{array}{l}4 / 11 \\
5 / 11\end{array}$ \\
\hline $\begin{array}{l}\text { Gram-negative cocci } \\
\text { Vellonella } \mathrm{sp} \text {. }\end{array}$ & 39 & 6 & & $5 / 11$ \\
\hline $\begin{array}{l}\mathrm{H}_{2} \mathrm{~S}^{+} \\
\mathrm{H}_{2} \mathrm{~S}^{-}\end{array}$ & $\begin{array}{r}33 \\
6\end{array}$ & $\begin{array}{l}5 \\
1\end{array}$ & $\begin{array}{l}0-32 \\
0-5\end{array}$ & $\begin{array}{l}5111 \\
311\end{array}$ \\
\hline Total isolates & 653 & $99 \cdot 6$ & & \\
\hline
\end{tabular}

* Number of subjects in which isolates were recovered from high dilutions of plaque.

D, E and $\mathrm{H}$ antisera (Difco), but did give a $2+$ agglutination with MG sera. They formed an ethanol-precipitable polysaccharide in sucrose broth.

These isolates could not be readily speciated as they possessed characteristics of both Strep. sanguis and Strep. mitis. The ability to form $\mathrm{NH}_{3}$ from arginine would

TABLE 5. CHARACTERISTICS OF SELECTED STREPTOCOCCAL ISOLATES

\begin{tabular}{|c|c|c|c|c|c|c|c|}
\hline \multirow{6}{*}{$\begin{array}{l}\text { Number of strains } \\
\text { Carbohydrate fermentation } \\
1 \% \text { mannitol } \\
1 \% \text { salicin } \\
1 \% \text { inulin }\end{array}$} & \multirow{3}{*}{$\frac{\begin{array}{c}\text { Plymouth } \\
\text { isolates }\end{array}}{15}$} & \multicolumn{3}{|c|}{ Carlsson groups* } & \multicolumn{3}{|c|}{ Guggenheim biotypes } \\
\hline & & $\mathrm{V}: \mathrm{B}$ & IV & $1: \mathrm{B}$ & & & \\
\hline & & 12 & 7 & 25 & & & \\
\hline & $0 \ddagger$ & 0 & 0 & 0 & - & - & $-\infty$ \\
\hline & $10^{+}$ & 10 & 7 & 25 & + & + & \pm \\
\hline & 0 & 1 & 0 & 24 & 5 & - & $=$ \\
\hline Esculin hydrolysis & 0 & 0 & 5 & 16 & to & $\cdots$ & \pm \\
\hline $\mathrm{NH}_{3}$ from arginine & 15 & 12 & 0 & 25 & $i$ & $+\frac{4}{3}$ & + \\
\hline $\begin{array}{l}\text { Acid clot } \\
\text { A }\end{array}$ & 15 & & & & 小 & $T$ & - \\
\hline Reduction & 15 & & & & 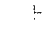 & $\because$ & -- \\
\hline Growth in & & & & & & & \\
\hline $\begin{array}{l}4 \% \mathrm{NaCl} \\
5 \% \text { bile }\end{array}$ & 0 & $\begin{array}{l}1 \\
2\end{array}$ & $\begin{array}{l}0 \\
3\end{array}$ & 0 & & & \\
\hline $\begin{array}{l}10 \% \text { bile } \\
40 \% \text { bile }\end{array}$ & li & & & & $\therefore$ & - & - \\
\hline
\end{tabular}

* Carlsson, J. 1968.

+ GugGenkeim, B. 1968.

$\$$ Number positive.

suggest that they are similar to isolates described by CARLSSON (1968), i.e. Groups V:B and I:B and by Guggenheim (1968), i.e. Biotypes 32, 38, and 42 (Table 5). However, the ability to grow in 40 per cent bile differentiates the Plymouth isolates from Group $V: B$, which it most nearly resembles. Other related groups are shown in Table 5. 


\section{Gram-positive rods}

Two hundred and thirty-two Gram-positive rods were isolated from the eleven subjects. A significant number of isolates, i.e. 8.4 per cent, were anaerobic, Grampositive sporulating rods and wcre identificd as Clostridium species. These organisms had subterminal oval spores, were motile, nitrate-variable, $\mathrm{H}_{2} \mathrm{~S}$-positive, gelatinpositive, indole-negative, and variable in regard to esculin hydrolysis. They were mainly nonfermentative or weakly fermentative. Acid end-product analysis of growth in PYG broth suggested that several groups were present. One group formed acetic, butyric, isovaleric, isobutyric, valeric, succinic, lactic and traces of propionic acids. Another group formed isocaproic acid among other volatile acids. The taxonomic information available was not adequate to speciate these isolates at present. However, the limited biochemical profile suggested that strains of $\mathrm{Cl}$. sporogenes, $\mathrm{Cl}$. subterminale, $\mathrm{Cl}$. hastiforme, and $\mathrm{Cl}$. histolyticum were present (VIRGINIA POLYTECH. InSTITUTE LAB., ANAEROBE Lab., 1970).

Fluorescent antibody reagents were used to contirm the presence of Clostridium in the plaque samples. Rabbits were immunized with several of the Clostridium isolates. The sera obtained were conjugated with fluorescein isothiocyanate and used to stain plaque smears made from the original plaque dilution (see Materials and Methods). Many, but not all, plaques contained organisms which gave a 3 or $4+$ fluorescence with these Clostridium antisera.

Fourteen per cent of the isolates were Gram-positive, filamentous, branching rods suggestive of Actinomyces species. These organisms were present in every child. These organisms were nitrate-positive, $\mathrm{H}_{2} \mathrm{~S}$-negative, indole-negative and gelatin-negative. They did not grow well in the $\mathrm{CB}$ and usually did not lower the $\mathrm{pH}$ below $5 \cdot 5$. Growth of representative strains in PYG broth was accompanied by production of acetic, lactic and succinic acids.

Seven per cent of the isolates were nitrate-negative, $\mathrm{H}_{2} \mathrm{~S}$-positive, indole-negative, gelatin-negative, Gram-positive rods. They were either weakly fermentative or fermentative. Acid end-products formed in PYG broth included acetic, isovaleric, lactic, succinic and butyric acids.

Two other groups of Gram-positive rods could be recognized. Four per cent of the isolates were nitrate-negative, $\mathrm{H}_{2} \mathrm{~S}$-negative, indole-negative and non-fermentative. Two per cent of the strains were nitrate-positive, $\mathrm{H}_{2} \mathrm{~S}$-positive and weakly fermentative. These last three groups could not be speciated and presumably are diphtheroids.

The Gram-negative rods comprised 17 per cent of the cultivable flora and were found in each subject. Black pigment forming Bacteroides melaninogenicus averaged 5.6 per cent of the isolates. These strains were nitrate-negative, indole-variable, gelatin-positive and $\mathrm{H}_{2} \mathrm{~S}$-positive. They were weakly to nonfermentative. These organisms were present in 8 of the 11 subjects and ranged as high as 22 per cent of the isolates in one subject. Fusobacterium species accounted for 6.8 per cent of the isolates. These organisms were also weakly to non-fermentative, gelatin-negative, nitrate-negative, $\mathrm{H}_{2} \mathrm{~S}$-positive and indole-variable. These fusiforms were identified primarily by colonial and single cell morphology and the biochemical tests which were confirmatory 
(LOESCHE and GibBONS, 1965). A small group of fermentative, nitrate-negative, $\mathrm{H}_{2} \mathrm{~S}-$ negative, gelatin-negative, and indole-negative strains were found in 4 subjects and presumably were Bacteroides species (LoESCHE, SoCransky and GibBons, 1964). Another group, which could not be identified, accounted for $2 \cdot 3$ per cent of the isolates and were nitrate-positive, $\mathrm{H}_{2} \mathrm{~S}$-negative, gelatin-negative, indole-negative and fermentative. They were excluded from the Bacteroides group on the basis of being nitratepositive.

The Gram-negative cocci were identified as Veillonella species and were found to comprise 6 per cent of the cultivable flora. They were present in only 5 subjects. In one subject, they were a major group accounting for 33 per cent of the isolates. These organisms were non-fermentative, nitrate-positive, $\mathrm{H}_{2} \mathrm{~S}$-variable, gelatin-negative and indole-negative. Representative strains formed acetate and propionate when grown in PYG broth. These characteristics are compatible with the description provided by Rogosa (1964) for the genus Veillonella.

\section{DISCUSSION}

The quantitative recovery of bacteria from the dental gingival surfaces is complicated by the unusual sensitivity of these organisms to oxygen. Gordon, STUTMan and LOESCHE (1971) showed that an exposure to atmospheric oxygen of only 20-30 min during the plating of gingival plaque samples reduced the recoveries from 67 to 20 per cent. ARANKi et al. (1969) showed that a system of complete anaerobiosis, i.e. anaerobic chamber, tripled the recoveries of bacteria from gingival samples over that obtained with anaerobic jar procedures. In the present study, the additional problem of survival of anaerobic organisms during the 2-3 hr transport of the samples back to the laboratory had to be considered. GaStrin, KallingS and MARCETIC (1968) have shown that the currently available transport media, i.e. Stuart, VMG, and SBL are inadequate for the quantitative recovery of bacteria. When 18 pure cultures of medically important bacteria were placed in these transport media, 90-99 per cent of the inocula did not survive the first hour. To overcome these difficulties, special precautions were taken in the present study to minimize exposure of the plaque to atmospheric oxygen and an oxidizing environment. Plaque samples were exposed to room atmosphere for about $10-20 \mathrm{sec}$ before immersion in the DTT poised transport medium and were subsequently never exposed to oxygen. Dithiothreitol was chosen as the reducing agent because of its low redox potential $(-0.33 \mathrm{~V}$ at $\mathrm{pH} 7)$, and its minimal tendency to be oxidized directly by air (CLELAND, 1964). The number of colonies which grew on the modified M10 medium accounted for 33 per cent of the cell units seen in the microscopic count (Table 2). The ratio of anaerobic to aerobic recoveries was about 4 . This ratio, when anaerobic jars have been employed, is about 2 (Gibbons et al., 1963, 1964; Gordon, Stutman and Loesche, 1971). These results would indicate that the procedures employed were partially successful in overcoming the difficulties in culturing specimens comprised primarily of anaerobes.

The precautions taken to minimize oxygen exposure meant that the plaque samples were not weighed. In order to calculate the bacterial density of these plaque samples, the microscopic count per unit dry weight for plaque taken from other sites 
in the same mouth at the same time was determined and a proportional equation was used to derive the weight of the cultured sample. This calculation makes the assumption that the number of bacterial units per unit plaque weight is the same in all intraoral sites and is essentially the same assumption that was made when pooled plaque samples were used (MORRIS, 1953; GibBons et al., 1963, 1964; GoRdon, STUTMAN and LOESCHE, 1971). However, site to site proportional variability may exist (PoOLE and GILMOUR, 1971).

Once the toxic exposure to oxygen has been minimized, the recovery of bacteria from plaque samples, or for that matter from any specimen taken from the mucous membranes of mammals, will depend upon the availability of essential nutrients in the primary isolation medium. The ideal medium presumably would be one that provides the nutrients found in the natural habitat of the bacteria and most likely would mimic the composition of the biological fluid(s) which bathe that environment. CALDWELL and BRYANT (1966) have developed medium M10 which is based upon the composition of rumen fluid. This medium has been demonstrated to be excellent for the isolation of rumen bacteria (CALDWELL and BRYANT, 1966), anaerobic sewer sludge bacteria (MaH and Sussman, 1967) and faecal bacteria (Eller, Crabill and BRYANT, 1971).

In the present investigation, medium M10 was modified by the deletion of starch and cellobiose and by the addition of blood, glucose, lactate, formate, nitrate and menadione (Table 1). Preliminary studies suggested that the modified M10 medium was superior to brain-heart infusion medium supplemented with blood, menadione and nitrate in the isolation of bacteria from plaque samples. For this reason modified M10 was used throughout the study.

A possible explanation as to why the modified M10 yielded excellent recoveries is that the low level of glucose will not allow fast-growing acidogenic bacteria such as the streptococci to lower the $\mathrm{pH}$ to levels which would inhibit the growth of slower growing organisms. However, the present results do not demonstrate its superiority over other primary isolation media in the quantitative rccovery of oral plaque bacteria.

In this regard, MM10 should be compared with the nutrient broth-cysteine-haemin $\left(\mathrm{N}_{2} \mathrm{CH}\right)$ medium shown by GILMOUR and Poole (1970) to permit recoveries of about $11 \cdot 3 \pm 2 \cdot 5 \times 10^{7}$ organisms per mg plaque wet weight. The $\mathrm{N}_{2} \mathrm{CH}$ medium is easier to prepare than the MM10 medium. In the present study, our viable counts were obtained on 2-3-hr-old samples and our microscopic counts were referred to a dry weight basis, thereby precluding a direct comparison with the data of GILMOUR and POOLE (1970). However, a calculation is possible in that the dry weight of our plaque samples accounted for about one fourth of the plaque wet weight (LoEscHE and GREEN, 1972). When the dry weight values are converted to a wet weight basis, the anaerobic viable plate count on MM10 amounts to about $10.0 \times 10^{7} / \mathrm{mg}$ plaque wet weight.

The organisms recovered from plaque samples have usually been difficult to identify because of (1) incomplete descriptions in the literature and (2) the introduction of a new technique, i.e. complete anaerobiosis, usually permits recoveries of organism hithertofore undescribed. The organisms recovered in this study were no 
exception. The most common isolates were streptococci strains. Colonial growth on MST showed that Strep. mutans and Strep. salivarius were present in low numbers, if at all. A small group of streptococcal strains were studied in greater detail. Their ability to form ammonia from arginine and not ferment inulin or esculin made them similar to the Strep. mitis found in Group V:B of CARLSson (1968) and possibly to biotype 38 of GugGENHEIM (1968). The Plymouth isolates were able to grow in the presence of 40 per cent bile and to form ethanol precipable polysaccharide which would distinguish these isolates from group $V: B$ and biotype 38. Recently $D E$ STOPPELAAR (1971) has reported on the occurrence of Strep. sanguis strains that grow in 40 per cent bile and produce ammonia from arginine. These considerations would indicate that the Plymouth isolates possess attributes of both Strep. mitis and Strep. sanguis and cannot be properly speciated at this time. The data do not permit the assumption that all the streptococci recovered would belong to this onc group. A larger group of 42 isolates showed variability in regard to the various tests, but all strains produced ammonia from arginine. It may be that ammonia production from arginine is an important and stable characteristic of the streptococci isolated from these plaque samples. Also the relationship of these isolates to enterococci needs to be determined. The inability to detect Strep. mutans in high numbers in the 11 subjects could be a reason for the low caries experience found in these individuals.

The demonstration of Clostridium species in these plaque samples was unexpected. Previous cultural studies of plaque taken from non-institutionalized subjects (MORRIS, 1953; Gibbons et al., 1963, 1964; Howell, Rizzo and Paul, 1965; Aranki et al., 1969) did not disclose the presence of Clostridium. Also investigations of samples taken from periodontally diseased pockets did not show clostridia either by darkfield examinations (RoSEBURY, MACDONALD and ClARK, 1950) or by cultural methods (DWYer and SoCransky, 1968; MCMINn and CrawFord, 1970). Recently the presence of clostridia in periodontal debris has been reported (VAN REENEN and COOGAN, 1970) and Clostridium welchii has been isolated from carious dentine (HARTLES and MCDonald, 1951). However, in these two studies, a high dilution technique was not used, and the clostridia eventually isolated could have been present in low numbers or actually been transient in nature. The present findings show that Clostridium species comprised about 8 per cent of the total cultivable flora and therefore are numerically prominent in the tooth surface plaque of these institutionalized subjects. The presence of these organisms in plaque was confirmed by fluorescent antibody reagents. The Plymouth subjects have ample exposure to soil and faecal contamination as they spend considerable time on the floor and in the lavatories. Thus it may not be surprising that in this population, clostridia can be isolated from the oral cavity. Whether the presence of clostridia contributes to the early breakdown of periodontal tissues that is common in institutionalized mentally retarded individuals (Swallow, 1964, Cutress, 1971a, 1971b) remains to be demonstrated. In this regard, the possible presence of $\mathrm{Cl}$. histolyticum in plaque samples may be of clinical significance as this organism possesses a potent extracellular collagenase (SMITH and HoldEMAN, 1968).

The organisms classified as Actinomyces species need additional study. They were second only to the streptococci in prevalence and in numerical importance. Their 
biochemical characteristics, with one exception, were compatible with these isolates being strains of Actinomyces israeli, Act. naeslundii, Act. viscosus or Act. odontolyticus (Smith and Holdeman, 1968). The exception was the inability of our isolates to acidify the CB medium.

Bacteroides melaninogenicus was a conspicuous organism in these plaque samples. This contrasts with the findings of GibBons et al. (1964) where B. melaninogenicus was not detected in tooth surface plaque taken from normal individuals. MESKIN, FARSHT and ANDERSON (1968) reported an increased prevalence of B. melaninogenicus in institutionalized subjects, which would be in agreement with our findings. However, Cutress, BRown and GuY (1970) found B. melaninogenicus in their sampling of institutionalized children to account for less than 0.2 per cent of the total viable count. These workers might have lost $B$. melaninogenicus during the transport and aerobic manipulation of their samples.

On the basis of this partial characterization of the supragingival plaque isolates from the Plymouth subjects, it would seem that this flora differed from the supragingival plaque isolates recovered by GiBBons et al. (1964) from normal subjects. B. melaninogenicus, Fusobacterium species and Clostridium species were found in the Plymouth subjects but not in the plaque of normal subjects. Even spirochaetes were present on darkfield examination prior to dispersal of the sample. (The failure of the spirochaetes to grow on medium MM10 might reflect their lysing during the manipulation of the sample, that their nutritional needs were not met, or that they were present in numbers below our dilution range.) These observations suggest that the tooth surfaces in these individuals have been colonized by certain bacteria, with the exception of the Clostridium species, which apparently are restricted to the gingival crevice area in normal subjects (SOCRANSKY et al., 1963). The presence of Clostridium species may be unique to this population and might reflect the easy access institutionalized subjects have to soil and faecal contamination.

As the clinical situation between normal individuals and mentally retarded institutionalized subjects are dissimilar (CUTREss, 1971a, 1971b), some speculation as to the role the different isolates play in these clinical conditions is possible. However, the extrapolation of in-vitro pure culture results to the in-vivo condition must be considered as mainly setting up hypothesis for future studies, as the in-vitro and in-vivo metabolism of bacteria need not be identical (Gordon and GiBBONS, 1967).

The quantitative culturing of tooth surface plaque from normal subjects showed that about 84 per cent of the cultivable isolates fermented glucose (calculated from the data of GibBons et al., 1964) and that the overwhelming majority of isolates in early plaque are acidogenic streptococci (TheIlade and TheIlade, 1969). The plaque from the Plymouth subjects had by comparison only 50 per cent of the cultivable isolates lowering the $\mathrm{pH}$ in glucose broth below $5 \cdot 5$. Also, the streptococcal strains which comprised 38 per cent of the total Plymouth isolates and 76 per cent of the acidogenic isolates were distinctive in their ability to liberate ammonia from arginine. This might mean that, over a pH range of $5 \cdot 0-8 \cdot 5$ (NIvEN, SMILEY and SHERMan, 1942), these organisms, if arginine was present in their environment, could be contributing base equivalents to neutralize any acid which they produced. Thus, in vivo 
these streptococci may not contribute to any appreciable $\mathrm{pH}$ drop. The streptococci plus the high percentage of ammonia-producing species such as $B$. melaninogenicus, Fusobacterium sp. and the various Clostridium species would not be expected to produce a plaque capable of decalcifying enamel. Thus the bacteriological findings would seem to offer an explanation as to why the caries prevalence was so low in the Plymouth subjects.

The results of this study permit comment on the relationship between Strep. sanguis and caries. Many Strep. sanguis strains produce ammonia from arginine (CARLSSON, 1968; Guggenheim, 1968; DE StopPelaAR, 1971; Thomson, 1971). Also Strep. sanguis has not been associated with extensive caries in experimental animals (FITzGERALD, 1968, KRASSE and CARLSSON, 1970) nor related to smooth surface cavities in man (DE StoppelaAr, van Houte and Backer Dirks, 1969). In fact, a tendency toward a negative correlation between the presence of Strep. sanguis and dental caries in man (De StoppelaAr, van Houte and BaCker Dirks, 1969) and in monkeys (Bowen, 1965) has been reported. It may be that in Strep. sanguis the inability to cause caries and the ability to form ammonia from arginine are casually related. At pHs known to occur in plaque, these Strep. sanguis strains could be releasing two equivalents of a strong base which might effectively neutralize any acid in their immediate environment. Thus a plaque in which Strep. sanguis is the main streptococcal species may not in vivo be capable of achieving the acid $\mathrm{pH}$ necessary to dissolve the enamel surface.

Acknowledgements - This work was supported by grants D.E.-03011-03 and D.E.-02731-05 from the National Institute of Dental Research. The technical assistance of Mrs. JOAN RowAN and Mrs. JANICE STOLL is gratefully acknowledged.

\footnotetext{
Résumé-Des plaques de surfaces dentaires, prélevées chez 11 sujets, vivant en institution, sont mises en culture sur agar en chambre anaérobie. La récupération des bactéries dans un milieu anaérobie dilué d'extrait trypticase levure (MM 10) est d'environ $33 \pm 26$ pour cent de la numération microscopique. La croissance sur MM 10, dans des conditions anaérobies, avoisine $8 \pm 5$ pour cent. Le rapport de récupération des bactéries anaérobies par rapport aux aérobies sur MM 10 est d'environ 4. Six cent soixantc ct onze isolements ont donné des subcultures et ont pu être caractérisés partiellement. Environ la moitié des isolements ont été incapables d'abaisser le pH dans un bouillon de glucose en dessous de 5,5. Les streptocoques en constituent environ 38 pour cent et ont été retrouvés chez chaque sujet. Un sous-groupe de 15 souches a poussé sur 40 pour cent de bile, a formé du $\mathrm{NH}_{3}$ à partir de l'arginine et a fermenté la salicine, mais non l'inuline. Ces organismes présentent les caractéristiques du Strep. sanguis et du Strep. mitis. Diverses espèces d'Actinomyces constituent 14 pour cent et les Clostridium forment 8 pour cent de la flore cultivable. Bacteroides melaninogenicus, Fusobacterium et Veillonella constituent chacun environ 6 pour cent des isolements. Le caractère général de ces plaques semble indiquer qu'une flore microbienne du sillon gingival, contenant plusieurs especes susceptibles de fermenter les acides aminés, a colonisé les surfaces dentaires. Ces micro-organismes ne sont pas susceptibles de produire une plaque capable de décalcifier l'émail, ce qui pourrait expliquer la faible fréquence carieuse de ces sujets.
} 


\begin{abstract}
Zusammenfassung-Plaques wurde von den Zahnoberflächen von 11 institutionalisierten Personen entnommen und auf Agarplatten anaerob kultiviert. Die Wiedergewinnung der Mikroorganismen in einem anaerob inkubierten löslichen Tryptikase-Hefe-ExtraktMedium (MM 10) entsprach durchschnittlich $33 \pm 26$ Prozent der mikroskopischen Zählung. Das Wachstum auf MM 10 betrug unter aeroben Bedingungen durchschnittlich $8 \pm 5$ Prozent. Das anaerob zu aerobe Verhältnis der Wiedergewinnung auf Medium MM 10 betrug etwa 4.671 Isolate wuchsen auf Subkulturen und wurden teilweise charakterisiert. Etwa die Hälfte der Isolate war nicht dazu fähig, das pH in Glukosebrühe unter 5,5 zu senken. Streptokokken machten etwa 38 Prozent der Isolate aus und wurden bei jeder Person gefunden. Eine Untergruppe von 15 Stämmen wuchs in 40 Prozent Galle, bildete $\mathrm{NH}_{3}$ aus Arginin und fermentierte Salizin, jedoch nicht Inulin. Diese Isolate wiesen Charakteristika von Strep. sanguis und Strep. mitis auf. Verschiedene Actinomyces-species umfaßten etwa 14 Prozent, und Clostridium-species machten 8 Prozent der kultivierbaren Flora aus. Bacteroides melaninogenicus, FusobacteriumArten und Veillonella-Arten waren jeweils in etwa 6 Prozent der Isolate vorhanden. Der Gesamtcharakter dieser Plaque-Isolate legt es nahe, daß die Mikrofiora der Zahnfleischfurche, welche mehrere Aminosäure fermentierende Arten enthält, auf den Zahnoberflächen aufgewachsen waren. Es ist nicht zu erwarten, daß diese Mikroorganismen Plaques entwickeln, die den Schmelz zu entkalken vermögen; daraus dürfte sich erklären, warum diese Personen wenig Karies hatten.
\end{abstract}

\title{
REFERENCES
}

Aranki, A., Syed, S. A., Kenney, E. B. and Freter, R. 1969. Isolation of anaerobic bacteria from human gingiva and mouse cecum by means of a simplified glove box procedure. Appl. Microbiol. $17,568-576$.

BOWEN, W. H. 1965. A bacteriological study of experimental dental caries in monkeys, Int. dent.J. 15, $12-53$.

Caldwell, D. R. and BRyANT, M. P. 1966. Medium without rumen fluid for nonselective enumeration and isolation of rumen bacteria. Appl. Microbiol. 14, 794-801.

CARLSSON, J. 1968. A numerical taxonomic study of human oral streptococci. Odont. Revy 19, 137-160.

Cleland, W. W. 1964. Dithiothreitol, a new protective reagent for SH groups. Biochemistry 3, $480-482$.

Cutress, T. W. 1971a. Dental caries in trisomy 21. Archs oral Biol. 16, 1329-1344.

Cutress, T. W. 1971b. Periodontal disease and oral hygiene in trisomy 21. Archs oral Biol. 16, $1345-1355$.

Cutress, T. W., Brown, R. H. and Guy, E. M. 1970. Occurrence of some bacterial species in the dental plaque of trisomic 21 (mongoloid), other mentally retarded, and normal subjects. N.Z. Dent. J. 66, 153-161.

DANIELSSON, D. 1965. A membrane filter method for the demonstration of bacteria by the fluorescent antibody technique. Acta path. microbial. scand. 63, 597-603.

DE STOPPelaAR, J. D., VAN Houte, J. and BACKer DiRKS, O. 1969. The relationship between extracellular polysaccharide producing streptococci and smooth surface caries in 13 year old children. Caries Res. 3, 190-199.

DE STOPPELAAR, J. 1971. Streptococcus mutans, Streptococcus sanguis and dental caries. PhD thesis. Utrecht, The Netherlands.

DWYer, D. M., SoCranSKY, S. S. 1968. Predominant cultivable micro-organisms inhabiting periodontal pockets. Br. Dent. J. 124, 560-564.

Eller, C., Crabill, M. R. and Bryant, M. P. 1971. Anaerobic roll tube media for nonselective enumeration and isolation of bacteria in human feces, Appl. Microbiol. 22, 522-529.

Fitzgerald, R. J. 1968. Dental caries research in gnotobiotic animals. Caries Res. 2, 139-146.

Gastrin, B., Kallings, L. O. and Marcetic, A. 1968. The survival time for different bacteria in various transport media. Acta path. microbiol. scand. 74, 371-380.

Gibbons, R. J., Socransky, S. S., Sawyer, S., Kapsimal.ts, B. and MacDonald, J. B. 1963. The microbiota of the gingival crevice area of man. II. The predominant cultivable organisms. Archs oral Biol. 8, 281-289.

Gibbons, R. J., Socransky, S. S., de Araujo, W. C. and van Houte, J. 1964. Studies of the predominant cultivable microbiota of dental plaque. Archs oral Biol. 9, 365-370. 
Gilmour, M. N. and Poole, A. E. 1970. Growth stimulation of the mixed microbial flora of human dental plaques by haemin. Archs oral Biol. 15, 1343-1353.

Gordon, D. F., Stutman, M. and Loescire, W. J. 1971. Improved isolation of anaerobic bacteria from the gingival crevice area of man. Appl. Microbiol. 21, 1046-1050.

Gordon, D. F. and GibBons, R. J. 1967. Glycolytic activity of Streptococcus mitis grown in vitro and in gnotobiotic animals. $J$. Bacteriol. 93, 1735-1736.

Guggenhetm, B. 1968. Streptococci of dental plaques. Caries Res. 2, 147-163.

Hartles, R. L. and MCDonald, N. D. 1951. The isolation of Clostridium welchii from human teeth. Br. dent. J. 91, 197.

Howell, A., Rizzo, A. and PAul, F. 1965. Cultivable bacteria in developing and mature human dental calculus. Archs oral Biol. 10, 307-313.

JABlon, J. M., Ferrer, T. and ZinNer, D. D. 1971. Colonial differentiation of Streptococcus mutans by the fluorescent-antibody technique. International Assoc. for Dent. Res. Preprinted abstracts 49th Gen. Meeting, Abstract No. 50.

Krasse, B. and CARLSson, J. 1970. Various types of streptococci and experimental caries in hamsters. Archs oral Biol. 15, 25-32.

KleinberG, I. 1970. Biochemistry of the dental plaque. In: Aduances in Oral Biolngy (edited hy Staple, P. H.) Vol., 4, pp. 43-90. Academic Press, New York.

LoESCHE, W. J. 1968. Importance of nutrition in gingival crevice microbial ecology. Periodontics 6, 245-249.

Loesche, W. J. and GibBons, R. J. 1965. A practical scheme for the taxonomy of oral Gram negative anaerobic rods. Archs oral Biol. 10, 723-725.

LOESCHE, W. J. and GibBONS, R. J. 1966. Influence of nutrition on the ecology and cariogenicity of the oral microflora. In: The Science of Nutrition and Its Application to Clinical Dentistry (edited by Nizel, A. E.), pp. 305-317. W. B. Saunders, Philadelphia.

LOESCHE, W. J. and GREen, E. 1972. Comparison of various plaque parameters in individuals with poor oral hygiene. J. Periodont. Res. (in press).

Loesche, W. J., Socransky, S. S. and Gibions, R. J. 1964. Bactervides oralis, proposed new species isolated from the oral cavity of man. J. Bacteriol. 88, 1329-1337.

MacDonald, J. B. and GibBons, R. J. 1962. The relationship of indigenous bacteria to periodontal disease. J. dent. Res. 41, 320-326.

Maf, R. A. and Sussman, C. 1967. Microbiology of anaerobic sludge fermentation. I. Enumeration of the non-methanogenic anaerobic bacteria. Appl. Microbiol. 16, 358-361.

MCMinn, M. T. and Crawford, J. J., 1970. Recovery of anaerobic micro-organisms from clinical specimens in prereduced media versus recovery by routine clinical laboratory mcthods. Appl. Microbiol. 19, 207-213.

Meskin, L. H., FARSht, E. M. and ANDERson, D. L. 1968. Prevalence of Bacteroides melaninogenicus in the gingival crevice area of institutionalized trisomy 21 and cerebral palsy patients and normal children. J. Periodont. 39, 326-328.

Morris, E. O. 1953. The bacteriology of the oral cavity. IIA Methods used in the study of the oral flora. IIB Lactobacillus. Br. Dent. J. 95, 259-270.

Niven, C. F., Smiley, K. L. and Sherman, J. M. 1942. The hydrolysis of arginine by streptococci. J. Bacteriol. 43, 651-660.

Poole, A. E. and Gilmour, M. N. 1971. The variability of unstandardized plaques obtained from single or multiple subjects. Archs oral Biol. 16, 681-687.

RAMFJORD, S. 1959. Indices for prevalence and incidence of periodontal disease. J. Periodont. 30, 51-59.

Rizzo, A. 1967. Rabbit corneal irrigation as a model system for studies on the relative toxicity of bacterial products implicated in periodontal disease. J. Periodont. 38, 491-497.

Rogosa, M. 1964. The genus Veillonella. I. General cultural, ecological and biochemical considerations. J. Bacteriol. 87, 162-170.

Rosebury, T., MacDonald, J. B. and Clark, A. R. 1950. A bacteriologic survey of gingival scrapings from periodontal infections by direct examination, guinea pig inoculation, and anaerobic cultivation. J. dent. Res, 29, 718-731.

Smith, L. D. S. and Holdeman, L. V. 1968. The Pathogenic Anaerobic Bacteria, pp. 386-387, 140-141. Charles Thomas, Springfield, Ill.

SOCIETY OF AMERICAN BACTERIOLOGISTS. 1957. Manual of Microbiological Methods. McGraw-Hill, New York. 
Socransky, S. S., Gibbons, R. J., Dale, A. C., Bortnick, L., Rosenthal, E., and MacDonald, J. B. 1963. The microbiota of the gingival crevice area of man. I. Total microscopic and viable counts and counts of specific organisms. Archs oral Biol. 8, 275-280.

SPEARS, R. W. and R. Freter, 1967. Improved isolation of anaerobic bacteria from the mouse cecum by maintaining continuous strict anaerobiosis. Proc. Soc. exp. biol. Med. 124, 903-909.

Swallow, J. N. 1964. Dental disease in children with Down's Syndrome. J. ment. defic. Res. 8, $102-118$.

Theilade, E. and THeIlaDE, J. 1969. Bacteriological and ultrastructural studies of developing dental plaque. In: Dental Plaque (edited by McHugH, W. D.), pp. 27-40. Thomson, Dundee, Scotland.

Tilomson, L. A. 1971. The development and testing of epidemiologic methods for sampling human dental plaque. PhD Thesis. Univ. of Michigan.

VAN REENAN, J. F. and COOGAN, M. M. 1970. Clostridia isolated from human mouths. Archs oral Biol. $15,845-848$.

Virginia Polytechnic Institute Laboratory. 1970. Outline of clinical methods in anaerobic bacteriology. The Anaerobe Laboratory, Virginia. Polytechnic Institute, Blacksburg, Va. 